\title{
Hyperthermia inhibits the proliferation and invasive ability of mouse malignant melanoma through TGF- $\beta_{1}$
}

\author{
HEKUN JIN ${ }^{1,2^{*}}$, XIAOXUE XIE ${ }^{2 *}$, BINGQIANG HU ${ }^{1}$, FUPING GAO ${ }^{4}$, JUMEI ZHOU ${ }^{1}$, \\ YINGYING ZHANG ${ }^{2}$, LEHUI DU ${ }^{3}$, XIAOWEN WANG ${ }^{3}$, LINGYUN ZHAO ${ }^{3}$, \\ XIAODONG ZHANG ${ }^{3}$, LIANGFANG SHEN $^{3}$, YUPING LIAO $^{2}$ and JINTIAN TANG ${ }^{3}$ \\ ${ }^{1}$ Xiangya Hospital of Central South University, Changsha 410008; ${ }^{2}$ Affiliated Tumor Hospital of Xiangya Medical School, \\ Central South University, Changsha 410013; ${ }^{3}$ Key Laboratory of Particle and Radiation Imaging, Ministry of Education, \\ Institute of Medical Physics and Engineering, Department of Engineering Physics, Tsinghua University, Beijing 100084; \\ ${ }^{4}$ Laboratory of Controllable Preparation and Application of Nanomaterials, Technical Institute of Physics and \\ Chemistry, Chinese Academy of Sciences (CAS), Beijing 100190, P.R. China
}

Received July 2, 2012; Accepted September 24, 2012

DOI: 10.3892/or.2012.2128

\begin{abstract}
The degradation of basement membranes by tumor cells involves secretion and activation of proteinases, such as the matrix metalloproteinases (MMPs), and results from an imbalance between their inhibitors and activators that are controlled by various growth factors or cytokines, among which TGF- $\beta_{1}$ may be the most intriguing. In order to study the therapeutic effect and molecular mechanism of hyperthermia on aggressive malignant melanoma, the expression levels of TGF- $\beta_{1}$ and Smad4 in B16F10 cells were dynamically analyzed by RT-PCR and western blotting for $24 \mathrm{~h}$ after heat treatment, from which time-dependent changes were determined. As expected, the proliferation and invasive ability of B16F10 cells were suppressed strongly by heat treatment. Furthermore, we compared the expression of TGF- $\beta_{1}$ in melanoma mouse models before and after magnetic fluid hyperthermia (MFH) in vivo. After hyperthermia, the tumor growth rate was reduced with a decline in TGF- $\beta_{1}$ protein expression. We conclude that changes in the TGF- $\beta_{1}$ pathway induced by hyperthermia may be an important part of the molecular mechanism involved.
\end{abstract}

\section{Introduction}

Cutaneous melanoma is one of the most aggressive human tumors, which originate from melanocytes, primarily in the

Correspondence to: Dr Jintian Tang, Key Laboratory of Particle and Radiation Imaging, Ministry of Education, Institute of Medical Physics and Engineering, Department of Engineering Physics, Tsinghua University, Beijing 100084, P.R. China

E-mail: tangjt@mail.tsinghua.edu.cn

*Contributed equally

Key words: malignant melanoma, TGF- $\beta_{1}$, MMP-2, MMP-9, invasiveness, proliferation skin, in the eye, the brain and mucosa. Melanoma affects patients in all age ranges and its incidence has dramatically risen over the past 50 years in industrialized countries. A particularly worrying feature of the tumor is its increasing incidence and its capacity for rapid metastatic spread. While very early stage melanoma (localized, stage I) is $>90 \%$ curable, disseminated stage IV melanoma leads to a life expectancy of less than a year (1). Metastases may establish in various organs, including skin, lungs, liver, brain and bone. Thus, inhibiting invasion and metastasis is the key to extending the survival time of these patients.

It is widely known that formation of metastasis starts with dissemination of tumor cells from the primary tumor and is a complex and multistep process. Degradation and remodeling of the extracellular matrix (ECM) and basement membranes by proteolytic enzymes are essential steps in these processes. Neutral proteinases of the matrix metalloproteinase (MMP) family actively participate in basement membrane proteolysis, acting mainly in the pericellular environment. Among the increasing number of ECM-degrading proteinases involved in cancer progression, most attention has been focused on the MMP family, mainly on MMP-2 and MMP-9. Increased expression of MMP-2 and MMP-9 was showed to correlate with an invasive phenotype of cancer cells $(2,3)$.

TGF- $\beta_{1}$ is a multifunctional cytokine that regulates cell growth, differentiation, migration, apoptosis and extracellular remodeling. In later stages of tumorigenesis, TGF- $\beta_{1}$ may function to promote cell invasion and metastasis through paracrine mechanisms, which could be involved in the promotion of angiogenesis and extracellular matrix protein synthesis (4). TGF- $\beta_{1}$ transduces its signals from the cell membrane to the nucleus through serine/threonine kinase receptors and their downstream effectors, Smad molecules. Increased expression and secretion of the different TGF- $\beta$ isoforms in melanoma cell lines when compared with normal melanocytes has been documented by several studies (5-8).

Clinical experiments have shown that hyperthermia, as part of multimodal regimens, is a tolerable and clinically practical 
supplementary therapy for patients with advanced malignant tumors, recurrent tumors and metastatic disease. Recently, it has been reported that hyperthermia delays tumor growth and inhibits lymph node metastasis in animal models. The in vivo experimental study of Nagashima et al found that local hyperthermia (heating at $43^{\circ} \mathrm{C}$ for $40 \mathrm{~min}$ ) inhibited lymph node metastasis of hamster oral squamous cell carcinoma when the primary tumor responded histologically to hyperthermia treatment (9). In vitro research aimed at trying to explain the mechanism has been carried out. One study demonstrated that a transient increase in intracellular cAMP was a critical signal for heat shock to induce tumor specific-suppression of MT1-MMP production and proMMP-2 activation in HT-1080 cells after heat shock at $42^{\circ} \mathrm{C}$ for $3 \mathrm{~h}$ (10). However, Nathanson et al (11) reported opposite results. B16-F1 melanomas that survived $43.5^{\circ} \mathrm{C}$ heat in vitro for $15 \mathrm{~min}$ and cultured for 10 days were able to bind significantly increased amounts of the basement membrane protein laminin. Motility of the heat-resistant B16-F1 cells in vitro toward the chemoattractant laminin was significantly increased. Thus, the increased expression levels of putative laminin receptors may be associated with increased metastasis of melanomas after subcurative hyperthermia.

Magnetic fluid hyperthermia (MFH) is a recent development, and a new approach for local targeting hyperthermia or thermoablation (12). In this technique, energy is coupled magnetically to iron oxide superparamagnetic nanoparticles in the target region. The magnetic fluid is injected directly into the target region and subsequently heated in an externally applied alternating magnetic field (AMF) to achieve better selectively targeted hyperthermia to the tumor. The excellent power absorption capabilities of magnetic fluids, attributable to the large number and surface of the heating elements, have been confirmed by in vitro experiments. Moreover, magnetic nanoparticles can be taken up by cancer cells and intracellularly heated (13-15). To date, hyperthermia induced by direct injection of magnetic nanoparticles has been successfully used in preclinical and even phase III studies of various malignant tumors such as mammary carcinoma, prostate cancer, malignant glioma and melanoma and has resulted in an encouragingly marked inhibition of tumor growth (16-23).

Our previous research showed that heating suppresses the invasive potential of MCF-7 cells and downregulates the expression of TGF- $\beta_{1}$ and MMPs (24). Therefore, we concluded that hyperthermia should be regarded as an important therapy for cancers which may metastasize at early stages. However, the molecular mechanisms are still unclear and no evidence exists in other types of carcinoma.

In order to further study the mechanisms involved in hyperthermia, we established an orthotopic mouse model of cutaneous malignant melanoma. Mouse malignant melanoma B16F10 cells are promising as an experimental model of invasion because of their metastatic biologic characteristics. In this study, we heated B16F10 cells in a water bath in vitro and by $\mathrm{MFH}$ in vivo respectively. Then, changes in the invasive ability and TGF- $\beta_{1}$ expression in malignant melanoma cells were analyzed.

\section{Materials and methods}

Cell culture. The murine B16F10 melanoma cell line was obtained from the National Centre for Cell Sciences and was grown and maintained in Dulbecco's modified Eagle's medium (DMEM; Gibco/Invitrogen, Carlsbad, CA, USA), containing $10 \% \mathrm{FBS}$ in a $5 \% \mathrm{CO}_{2}$ incubator at $37^{\circ} \mathrm{C}$.

Cell treatment. Exponential growing cells were sealed using parafilm in cell culture flasks ( $1 \times 10^{6}$ cells/flask) and immersed in a thermostated water bath at the indicated temperature (43, 45 and $47^{\circ} \mathrm{C}$ ) for $30 \mathrm{~min}$. The control group was treated at $37^{\circ} \mathrm{C}$ for $30 \mathrm{~min}$. The temperature of the medium increased quickly and reached the set temperatures within $3 \mathrm{~min}$. The temperature in the medium was monitored with a fiber optic thermometer probe (FX-9020; Anritsu Meter Co., Tokyo). After heating, the cells were immediately incubated at $37^{\circ} \mathrm{C}$ in $5 \% \mathrm{CO}_{2}$.

MTT assay. Cells were incubated for $4 \mathrm{~h}$ to restore stability after heating, and then were harvested, counted, and inoculated (at the appropriate concentrations in a volume of $100 \mu \mathrm{l}$ ) into 96-well microtiter plates, 8 replicates were prepared for each group. After different incubation times at $37^{\circ} \mathrm{C}$ in a humidified $5 \% \mathrm{CO}_{2}$ atmosphere, the MTT assay was performed. MTT (Sigma, St. Louis, MO) was dissolved at a concentration of $5 \mathrm{mg} / \mathrm{ml}$ in Hank's salt solution and filtered with a $0.45 \mu \mathrm{m}$ filter (in order to avoid MTT aggregates). MTT solution $(10 \mathrm{ml})$ was added to each well and also to the control wells without cells. After $4 \mathrm{~h}$ of incubation, microtiter plates were centrifuged at 2,000 rpm for $10 \mathrm{~min}$; medium was then removed, and $100 \mu \mathrm{l}$ of DMSO was added to each well. After thorough mixing with a mechanical plate mixer, absorbance of the wells was read in a scanning well microculture plate reader at test and reference wavelengths of 550 and $620 \mathrm{~nm}$, respectively. Absorbance values from all wells were corrected against the control absorbance levels.

Cell migration assay. B16F10 cells heated at different temperatures by water bath were allowed to form a monolayer on a fibronectin $(5 \mu \mathrm{g} / \mathrm{ml})$-coated surface. A wound was made in the monolayer of cells by scratching a line on the monolayer with a pipette tip. Cells were then washed with PBS to remove cell debris and fed with fresh culture medium. Cells were allowed to proliferate and migrate into the wound during the next $24 \mathrm{~h}$. Migration of cells into the wound was observed using a microscope (Olympus BX51, Tokyo, Japan). Three wounds were sampled for each treatment and experiments were carried out in triplicate.

Matrigel invasion and metastasis assays. The invasive activity of B16F10 cells after heating at different temperatures was assayed in a Transwell cell culture chamber $(6.5 \mathrm{~mm}, 8 \mu \mathrm{m}$ Costar, Corning). Polyvinylpyrrolidone-free polycarbonate filters were smeared with $8.0 \mu \mathrm{g}$ fibronectin (Genscrip cat. no: RP10840) in a volume of $10 \mu \mathrm{l}$ serum-free DMEM on the reverse side, and dried at room temperature. Matrigel (containing laminin, collagen type IV, heparan sulfate proteoglycan and entactin) (BD Biosciences cat. no: 356230) was diluted to $500 \mu \mathrm{g} / \mathrm{ml}$ with cold phosphate-buffered saline (PBS), applied to the upper surface of the filter (5 $\mu \mathrm{g} /$ filter), and dried at room temperature. B16F10 cells which were heated by water bath for $30 \mathrm{~min}$ and then incubated for $2 \mathrm{~h}$ at $37^{\circ} \mathrm{C}$ in $5 \% \mathrm{CO}_{2}$ were harvested with $1 \mathrm{mM}$ EDTA in PBS, 
washed twice and resuspended to give a final concentration of $2.0 \times 10^{6} / \mathrm{ml}$ in serum-free RPMI-1640 with $0.1 \%$ bovine serum albumin (BSA). Cell suspensions $(100 \mu \mathrm{l})$ were added to the upper compartment and the filter chamber was incubated for $24 \mathrm{~h}$ at $37^{\circ} \mathrm{C}$ in a $5 \% \mathrm{CO}_{2}$ atmosphere. The cells on the upper surface of the filters were removed by wiping them with a cotton swab. The filters were then stained with crystal violet for $30 \mathrm{~min}$. The cells that had invaded through Matrigel and reached to the reverse side were counted under a microscope in five predetermined fields at a magnification of $x 400$. Each assay was performed in triplicate.

Gelatin zymography. B16F10 cells were heated by water bath for $30 \mathrm{~min}$ as noted and then incubated for $24 \mathrm{~h}$ with serumfree DMEM at $37^{\circ} \mathrm{C}$ in $5 \% \mathrm{CO}_{2}$. The culture supernatant was collected by centrifugation and then concentrated by lyophilization. The extract was then subjected to zymography on 7.5\% SDS-PAGE (sodium dodecyl sulfate polyacrylamide gel electrophoresis) co-polymerized with $0.1 \%$ gelatin. Gel was washed in $2.5 \%$ Triton X-100 for 30 min to remove SDS and was then incubated overnight in a reaction buffer $(50 \mathrm{mM}$ Tris- $\mathrm{HCl} \mathrm{pH} 7.0,4.5 \mathrm{mM} \mathrm{CaCl}_{2}, 0.2 \mathrm{M} \mathrm{NaCl}$ ). After incubation, the gel was stained with $0.5 \%$ Coomassie Blue containing $30 \%$ methanol and $10 \%$ glacial acetic acid. The bands were visualized by destaining the gel with the solution containing $30 \%$ methanol and $10 \%$ glacial acetic acid. The experiments were repeated three times under similar conditions, and one experiment was selected for representation.

Western blot experiments. Whole cell lysates were prepared by lysing the cells on ice with a protein extraction kit (SBS, China) for $20 \mathrm{~min}$. Equal amounts of protein (30 $\mu \mathrm{g} / \mathrm{lane})$ were electrophoresed under non-reducing conditions on $10 \%$ acrylamide gels. After SDS-PAGE, proteins were transferred to a polyvinylidene difluoride membrane (Bio-Rad, USA). To block non-specific binding, the membrane was incubated in TBS with $0.1 \%$ Tween-20 (TBST) containing 5\% nonfat milk for $2 \mathrm{~h}$. Subsequently, the membrane was incubated for $2 \mathrm{~h}$ with antibodies against TGF- $\beta_{1}$ and Smad4 (Santa Cruz Biotechnology, Santa Cruz, CA, USA, 1:1000), respectively, in TBST with 5\% non-fat milk. After washing in TBST, horseradish peroxidase-conjugated anti-mouse or anti-rabbit IgG (Santa Cruz Biotechnology) was used as a secondary antibody (1:2000 in TBST with 2\% BSA, incubated for $1 \mathrm{~h}$ ). Each sample was also probed with an anti- $\beta$-actin antibody (Santa Cruz Biotechnology) as a loading control. Bands were scanned using a densitometer (GS-700, Bio-Rad), and quantification was performed using Quantity One 4.6.2 software (Bio-Rad).

RT-PCR analysis. The expression of TGF- $\beta_{1}$ and Smad4 mRNA was analyzed by semi-quantitative RT-PCR. B16F10 cells were heated by water bath for $30 \mathrm{~min}$ as noted and then incubated for $24 \mathrm{~h}$. Total RNA was extracted from the cells using TRIzol reagent (Invitrogen) respectively and $5 \mu \mathrm{g}$ RNA was used to synthesize cDNA using an RT-PCR kit (M-MLV) (KeyGEN, KGA1305) following the manufacturer's protocol. The cDNA was used to amplify the TGF- $\beta_{1}$ and Smad4 mRNA fragment, while the housekeeping gene $\beta$-actin was also amplified as an internal standard. The corresponding primer sequences were: $\beta$-actin forward, 5'-ACCTTCTACAATGAGCTGCGT-3' and

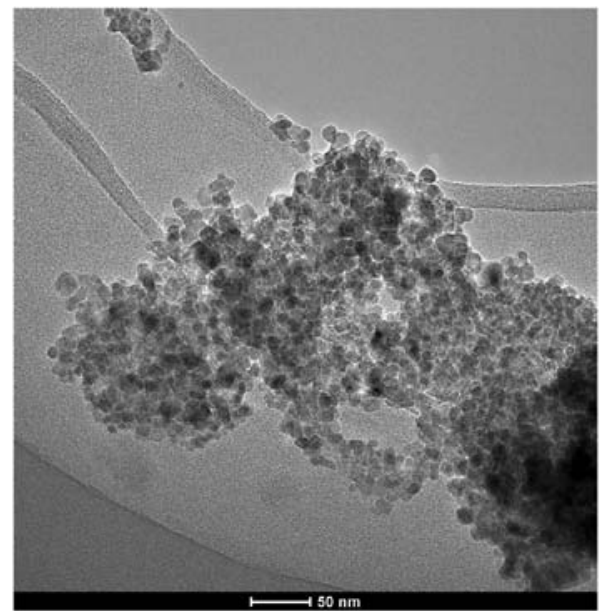

Figure 1. Magnetic nanoparticle.

reverse, 5'-ATAGCACAGCCTGGATAGCAA-3' (157 bp); TGF- $\beta_{1}$ forward, 5'-GGCCAGATCCTGTCCAAGC-3' and reverse, 5'-GTGGGTTTCCACCATTAGCAC-3' (201 bp); Smad4 forward, 5'-GTCTGAGCATTGTGCATAGTTTG-3' and reverse, 5'-GACGGGCATAGATCACATGAG-3' (246 bp).

The cycling program was performed as follows: 1 cycle of $94^{\circ} \mathrm{C}$ for $5 \mathrm{~min} ; 33$ cycles of $94^{\circ} \mathrm{C}$ for $30 \mathrm{sec}, 54^{\circ} \mathrm{C}$ for $45 \mathrm{sec}$, $72^{\circ} \mathrm{C}$ for $60 \mathrm{sec}$; followed by a final elongation step at $72^{\circ} \mathrm{C}$ for $10 \mathrm{~min}$. Then RT-PCR products were electrophoresed through a $1.5 \%$ agarose gel with ethidium bromide. The experiments were repeated three times under similar conditions, and one experiment was selected for representation.

Tumor model. Specific pathogen-free female C57BL/6 mice were purchased from Beijing Center for Disease Control and Prevention (China) and were maintained in our animal facility for at least 2 weeks before use. The mice were housed under specific pathogen-free conditions in a barrier facility with a 12-h light/dark cycle. The mouse model of melanoma was established by transplanting a $0.1-\mathrm{ml}$ cultured B16F10 cell suspension at a concentration of $1 \times 10^{7}$ cells $/ \mathrm{ml}$ into the subcutaneous tissue of the back of each mouse. Forty mice were randomized and divided into four groups: $45^{\circ} \mathrm{C}$ hyperthermia group $(\mathrm{H} 1), 50^{\circ} \mathrm{C}$ hyperthermia group $(\mathrm{H} 2)$, magnetic fluid group (M) and control group (C). Orthotopic tumors were staged for 7 days and reached $\sim 0.5 \mathrm{~cm}^{3}$ in size. The tumor-bearing mice of the $\mathrm{M}$ group, $\mathrm{H} 1$ group and $\mathrm{H} 2$ group were locally injected with magnetic fluid in the tumor area, then underwent radiation by an alternating magnetic field (AMF). The magnetic fluid (Fig. 1) was purchased from Anhui Jinke Magnetic Liquids Ltd. and consisted of uncoated and water-based particles of $\mathrm{Fe}_{3} \mathrm{O}_{4} \sim 10 \mathrm{~nm}$ in diameter, and the concentration of the ferrites in aqueous solution was $100 \mathrm{mg} / \mathrm{ml}$. The magnetic field applicator (Fig. 2) was produced by our laboratory at the Department of Engineering Physics, Tsinghua University, and the parameters of the AMF were carefully adjusted until a local tumor temperature $\left(45\right.$ or $\left.50^{\circ} \mathrm{C}\right)$ was maintained for 30 and $10 \mathrm{~min}$, respectively. After $24 \mathrm{~h}$, 3 mice from each group were sacrificed for anatomy to observe the magnetic fluid distribution and to prepare for the following immunohistochemistry tests. 


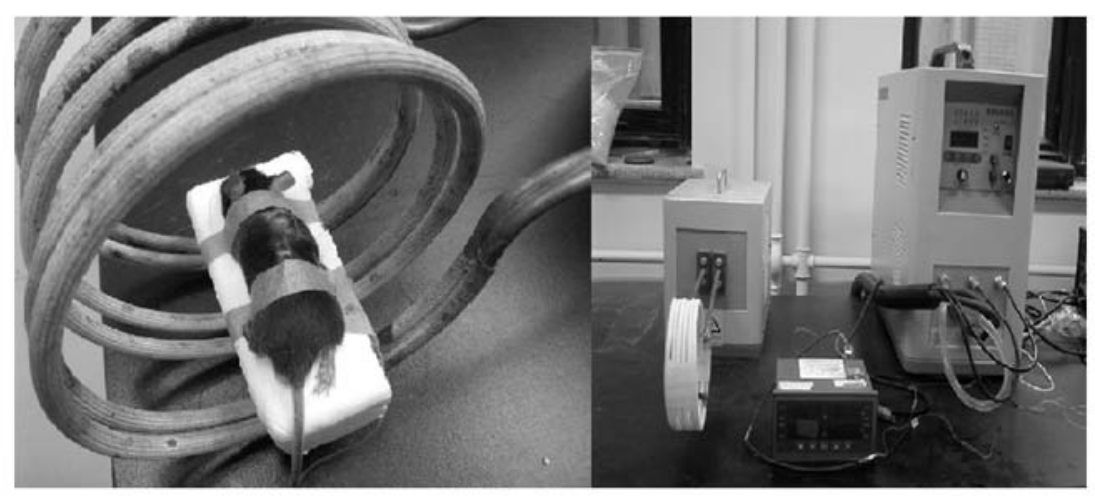

Figure 2. A mouse receiving treatment (left); magnetic field applicator (right) including induction coil, alternating current generator and temperature measuring equipment.

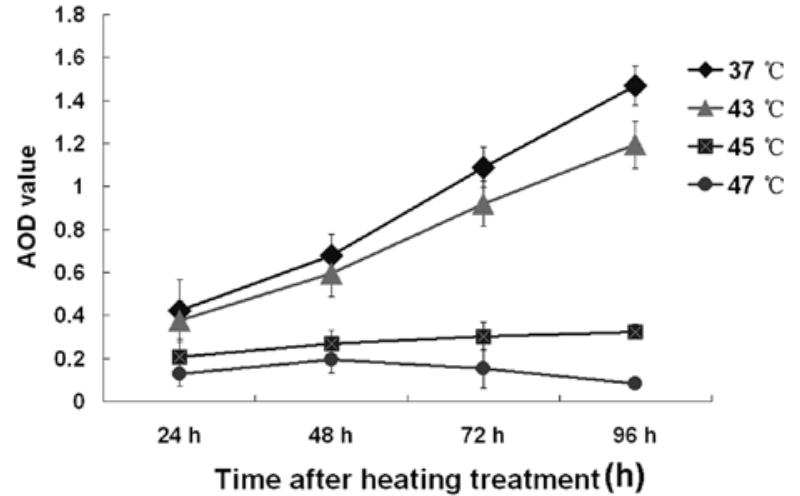

Figure 3. Proliferative activity of B16F10 cells after hyperthermia as tested by MTT assays.

Tumor growth was monitored at a defined regular interval ( 2 days) by measuring the diameters using a vernier caliper. Tumor volume was determined based on the following formula: Tumor volume $=0.5 \times \mathrm{a} \mathrm{x} \mathrm{b}^{2}$ ( $\mathrm{a}$ and $\mathrm{b}$ represent the maximal and minimal tumor diameter, respectively). Mice survival times were determined. After a 90-day follow-up period, all mice were sacrificed.

Immunohistochemistry. The paraffin-embedded tumor tissues were sectioned into $5-\mu \mathrm{m}$ slices, deparaffinized in xylene, rehydrated in graded ethanol concentrations $(100,95,70$, and $50 \%$ ), and finally submerged in phosphate-buffered saline (PBS). Endogenous peroxidase was blocked by incubation with $0.3 \% \mathrm{H}_{2} \mathrm{O}_{2}$ for $30 \mathrm{~min}$ in the dark, and then sections were placed in an autoclave with $0.01 \mathrm{M}$ sodium citrate solution at $121^{\circ} \mathrm{C}$ for $5 \mathrm{~min}$ for antigen retrieval. Immunohistochemical staining was performed using primary antibodies for TGF- $\beta_{1}$. The sections were incubated with antibodies (1:100) overnight at $4^{\circ} \mathrm{C}$ and then incubated with biotin-labeled anti-rabbit $\operatorname{IgG}$ (ZSGB-Bio, Beijing, China) at room temperature for $30 \mathrm{~min}$. The tissue sections were counterstained with hematoxylin, dehydrated in graded ethanol concentrations $(50,70,95$, and $100 \%$ ) and xylene, covered with glass coverslips, and then observed using a bright field microscope.

Statistical analysis. Statistical analysis was performed using SPSS (version 13.0). Data are expressed as means \pm SD for $n$ replicates as indicated in figure legends. One-way analysis of variance followed by an SNK test was used to assess significant differences between the control and experimental groups.

\section{Results}

Hyperthermia inhibits proliferation potential and mobility of B16F10 cells. B16F10 cells treated by water bath at 43,45 and $47^{\circ} \mathrm{C}$ for $30 \mathrm{~min}$ were then tested by MTT assay and scratchwounding assays. As shown in Fig. 3, the proliferative ability of the cells after being heated at 45 and $47^{\circ} \mathrm{C}$ was markedly higher than at $43^{\circ} \mathrm{C}(\mathrm{P}<0.05)$. As shown in Fig. 4 , the mobility of B16F10 cells was obviously decreased by heating at 45 and $47^{\circ} \mathrm{C}$.

Hyperthermia inhibits invasive and metastatic potential of B16F10 cells. We examined changes in the invasive and metastatic potential of B16F10 cells after hyperthermia treatment using a Matrigel invasion assay. Representative images of the Matrigel invasion assay showed a decrease in the number of invasive B16F10 cells after hyperthermia (x400) (Fig. 5A). Column data showed that hyperthermia decreased the invasiveness of $\mathrm{B} 16 \mathrm{~F} 10$ cells in a temperature-dependent manner (Fig. 5B). Compared with the control group $\left(37^{\circ} \mathrm{C}\right)$, B16F10 cells heated at 43,45 and $47^{\circ} \mathrm{C}$ showed significantly lower numbers of invasive cells $(\mathrm{P}<0.01)$.

Downregulation of MMP-2 and MMP-9 activity. In order to ascertain whether the downregulation of MMP-2 and MMP-9 in B16F10 cells is induced by hyperthermia, we examined the effect of hyperthermia treatment at different temperature points in the secretion and activity of MMP-2 and MMP-9 by gelatin zymographic analysis. As shown in Fig. 6, the white bands were areas degraded by MMP-2 and MMP-9. The corresponding image represents the quantitative analysis of the band intensities using a contour tool by Quantity One-4.6.2 (Basic) which clearly showed that hyperthermia treatment caused significant inhibition of the secretion and activity of MMP-2 and MMP-9 in B16F10 cells $(\mathrm{P}<0.01)$ and the decrease appeared to be temperature-dependent.

Regulation of the protein expression of TGF- $\beta_{1}$ and Smad4 by hyperthermia. Western blot analysis (Fig. 7A) was performed 

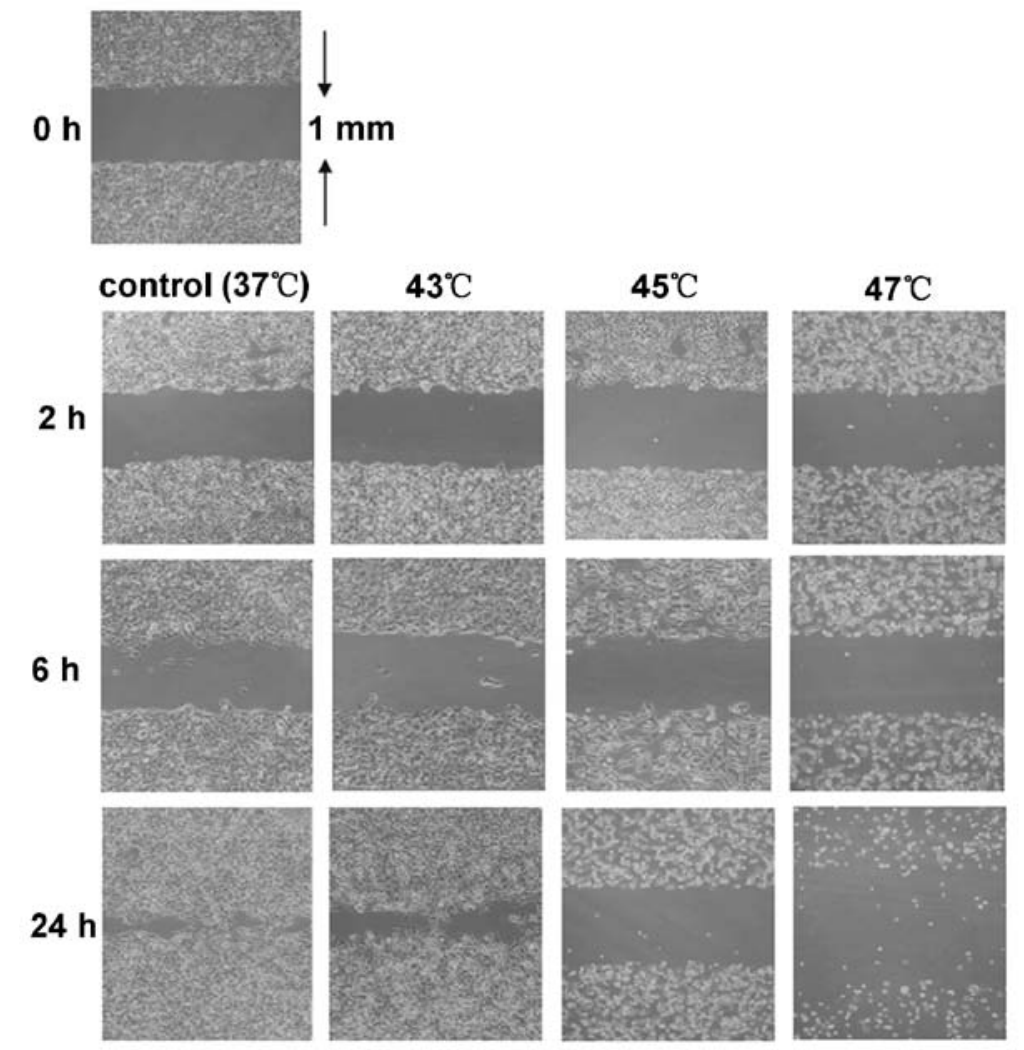

Figure 4. Changes in B16F10 cell mobility after hyperthermia.

A
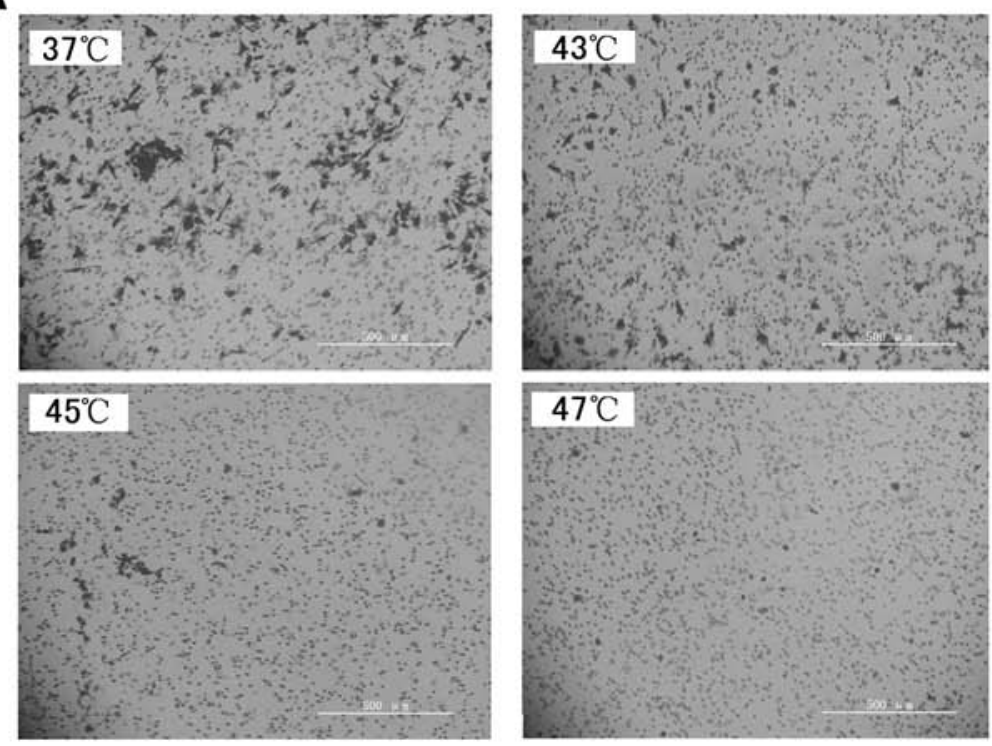

B

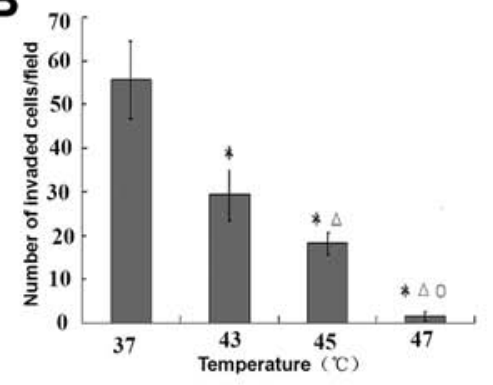

Figure 5. (A) Invasive and metastatic potentials of B16F10 cells after hyperthermia at different temperatures and (B) corresponding bar graph. "P $<0.01$ compared with control; ${ }^{\wedge} \mathrm{P}<0.01$ compared with the $43^{\circ} \mathrm{C}$ group; ${ }^{\circ} \mathrm{P}<0.01$ compared with the $45^{\circ} \mathrm{C}$ group $(\mathrm{n}=5)$.

to ascertain whether the protein expression of TGF- $\beta_{1} / \mathrm{Smad} 4$ in B16F10 cells is affected by hyperthermia. Fig. 7B shows the corresponding average optical densities of TGF- $\beta_{1}$ and Smad4 after different temperature treatments. The reduction showed temperature dependence for TGF- $\beta_{1}$, while the upregulation of Smad4 lasted for a short time at $43^{\circ} \mathrm{C}$ and $45^{\circ} \mathrm{C}$ but not at $47^{\circ} \mathrm{C}$. Moreover, at the higher temperature, the increase in $\mathrm{Smad} 4$ protein expression occurred earlier. The bar graph represents the corresponding average optical densities using Quantity One-4.6.2 (Basic).

Alteration of the mRNA expression of TGF- $\beta_{1}$, Smad 4 and $M M P s$. RT-PCR was performed to ascertain whether the mRNA expression of TGF- $\beta_{1}$ and Smad4 in B16F10 cells is 


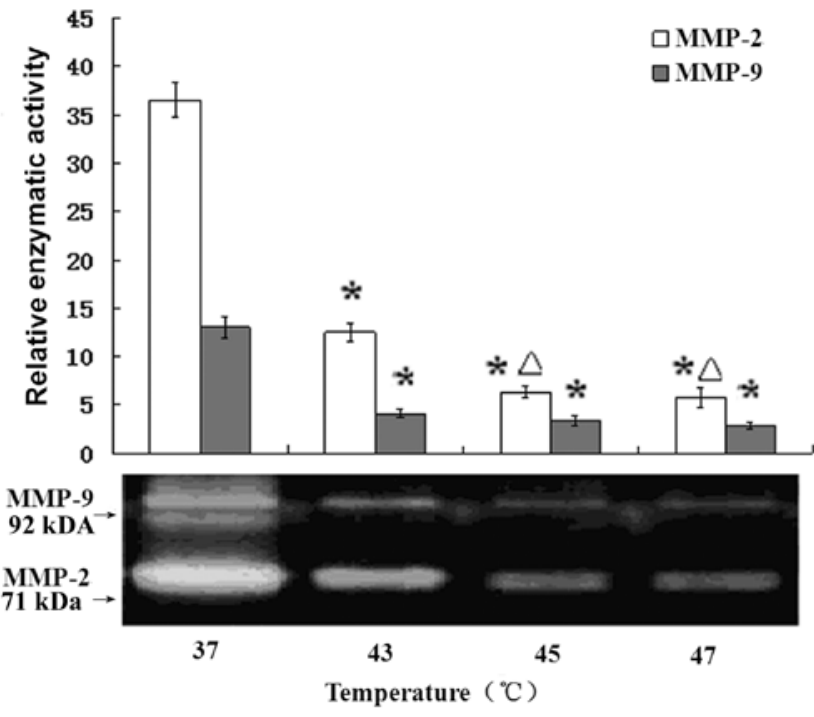

Figure 6. Gelatin zymographic analysis of MMP-2 and MMP-9. "P<0.01 compared with control; ${ }^{\circ} \mathrm{P}<0.01$ compared with the $43^{\circ} \mathrm{C}$ group $(\mathrm{n}=3)$.

suppressed by hyperthermia. As shown in Fig. 8 , the mRNA expression of TGF- $\beta_{1}$ was significantly reduced by hyperthermia when the temperature was above $43^{\circ} \mathrm{C}$, while the mRNA level of Smad4 did not change significantly.

Regulation of TGF- $\beta_{1}$ protein expression by hyperthermia in vivo. $\mathrm{MFH}$ at $45^{\circ} \mathrm{C}$ ( $\mathrm{H} 1$ group) and $50^{\circ} \mathrm{C}$ (H2 group) inhibited tumor growth. Compared with $45^{\circ} \mathrm{C}$ MFH (H1 group), $50^{\circ} \mathrm{C} \mathrm{MFH}$ (H2 group) had a greater inhibitive effect on tumor growth $(\mathrm{P}<0.05)$. The survival times of the mice in the $50^{\circ} \mathrm{C}$ $\mathrm{MFH} \mathrm{H} 2$ group and $47^{\circ} \mathrm{C} \mathrm{MFH} \mathrm{H} 1$ group were longer than that of the control group $(\mathrm{P}<0.05)$. Immunohistochemical assay showed that the expression of TGF- $\beta_{1}$ was markedly decreased in the $50^{\circ} \mathrm{C} \mathrm{MFH} \mathrm{H} 2$ group compared with the other groups $(\mathrm{P}<0.05)$ (Fig. 9).

Tumor growth inhibition and survival in the mouse model. In the in vivo study, no mice died during the MFH process as described above, and no infiltration of magnetic fluid was found in the surrounding tissue and organs. As shown in Fig. 10, the tumor growth rate of the control group and magnetic fluid group was significantly lower than $\mathrm{H} 1$ and $\mathrm{H} 2$ groups treated at 45 and $50^{\circ} \mathrm{C}$, respectively $(\mathrm{P}<0.05)$ and the survival period of the tumor-bearing mice which was observed for 90 days after tumor implantation showed that magnetic fluid hyperthermia (especially for $\mathrm{H} 2$ group at $50^{\circ} \mathrm{C}$ ) prolonged the life span of the mouse model significantly.

\section{Discussion}

Although melanomas represent only approximately $4 \%$ of all cutaneous cancers, they are responsible for $>80 \%$ of deaths from skin-related cancers (25). In its early stages, malignant melanoma can be cured by surgical resection, but once it has progressed to the metastatic stage it is extremely difficult to treat and does not respond to current therapeutic methods (such as radiation therapy and chemotherapy). In the present study, we explored hyperthermia as a prospective therapy for malignant melanoma.

It is no doubt that with temperatures higher than $43^{\circ} \mathrm{C}$, the cytotoxicity of hyperthermia becomes stronger. Our MTT assay showed that higher temperature hyperthermia strengthened the lethal effect. Moreover, the present study was the first attempt to study the effect of local hyperthermia with a heating temperature above $43^{\circ} \mathrm{C}$ on the invasive ability of malignant melanoma cells. Our results showed that migratory and invasive ability of the remnant carcinoma cells was suppressed after hyperthermia at 43,45 and $47^{\circ} \mathrm{C}$ for $30 \mathrm{~min}$, respectively.

A

Time

$2 \mathrm{~h}$

$12 \mathrm{~h}$

$24 \mathrm{~h}$

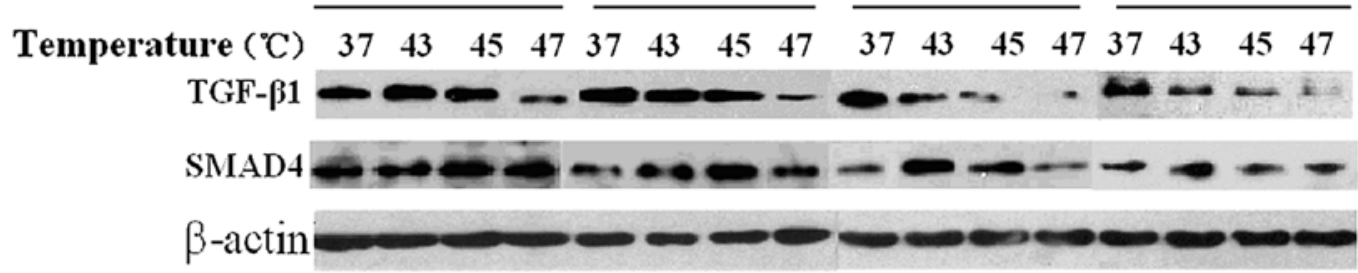

B

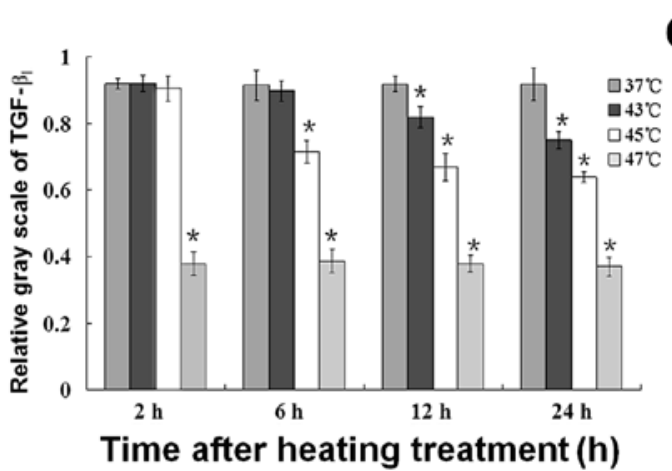

C

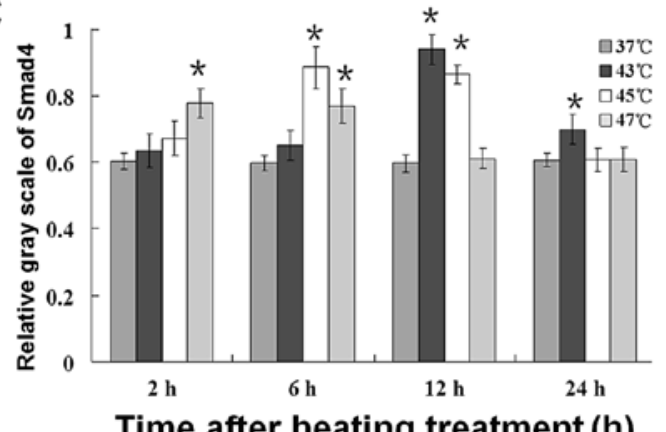

Figure 7. (A) Western blot assay of the protein expression of TGF- $\beta_{1}$ and Smad4 in B16F10 cells, and corresponding bar graphs for (B) TGF- $\beta_{1}$ and (C) Smad4 ${ }^{*} \mathrm{P}<0.05$ compared with control $(\mathrm{n}=3)$. 


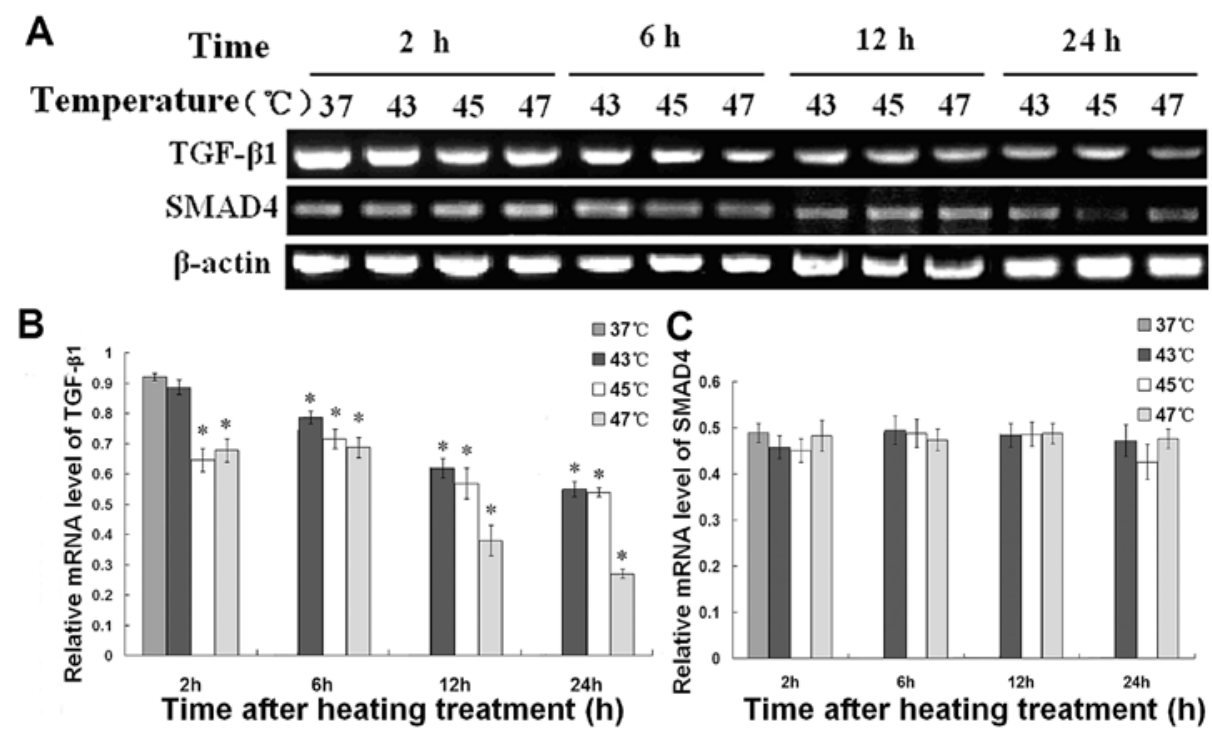

Figure 8. (A) mRNA-expression level of TGF- $\beta_{1}$ and Smad 4 in B16F10 cells, and the corresponding bar graphs for (B) TGF- $\beta_{1}$ and (C) Smad4. ${ }^{*} \mathrm{P}<0.01$ compared with control; $(\mathrm{n}=3)$.
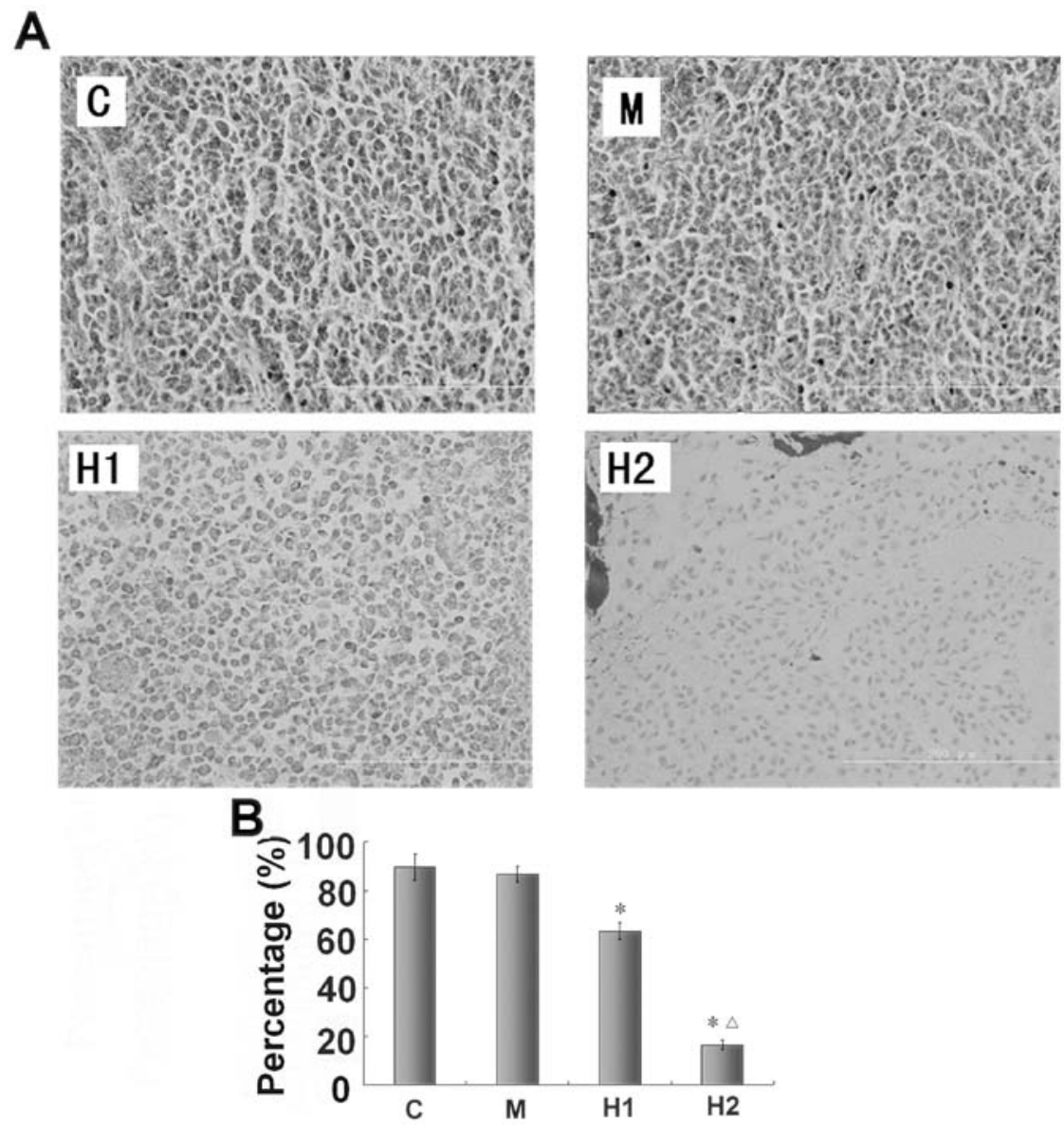

Figure 9. (A) Immunohistochemical imaging and (B) corresponding bar graph for TGF- $\beta_{1}$ protein expression of melanoma cells in (H1) $45^{\circ} \mathrm{C}$ hyperthermia groups, (H2) $50^{\circ} \mathrm{C}$ hyperthermia groups, (M) magnetic fluid groups and (C) control groups. ${ }^{*} \mathrm{P}<0.01$ compared with control; ${ }^{\triangle} \mathrm{P}<0.01$ compared with the $43^{\circ} \mathrm{C}$ group $(\mathrm{n}=5)$.

It is known that degradation of the basal lamina and extracellular matrix $(\mathrm{ECM})$ is crucial for invasion and metastasis of malignant cells. Among the currently known 24 types of human MMPs, MMP-2 (or gelatinase A) is most frequently overexpressed in cancer and is instrumental in cutting through basement membrane barriers (26-29). It was reported that 
A

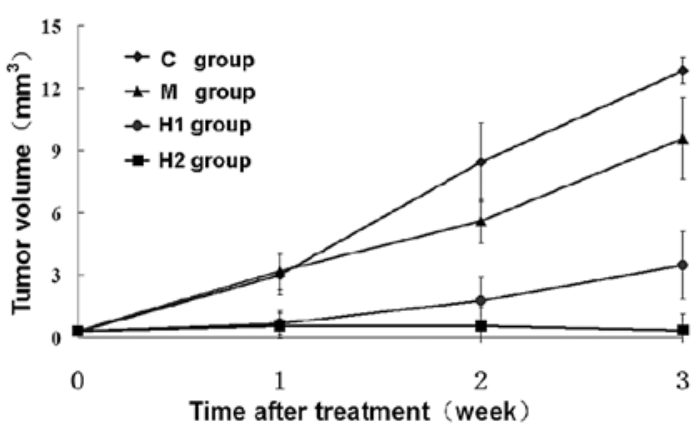

B

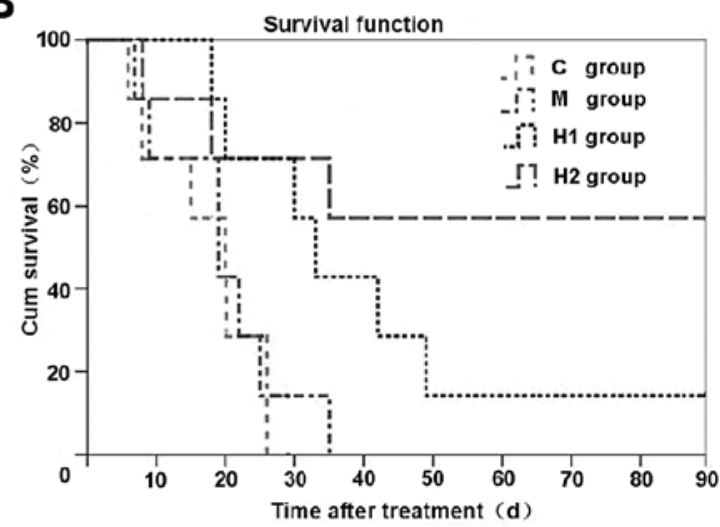

Figure 10. (A) Tumor growth rate and (B) survival time of mouse models in the $45^{\circ} \mathrm{C}$ hyperthermia group ( $\mathrm{H} 1$ group), $50^{\circ} \mathrm{C}$ hyperthermia group (H2 group), magnetic fluid group (M group) and control group (C group).

heat shock at $42^{\circ} \mathrm{C}$ suppressed the production of membranetype 1 MMP (MT1-MMP), which in turn inhibited MMP-2 activation and increased release of tissue inhibitor of MMP-2 from the cell surface (30). Consistent with this finding, our study revealed a similar effect on both MMP-2 and MMP-9 in malignant melanoma B16F10 cells by heating at higher temperature and for a shorter time.

Several investigators demonstrated that TGF- $\beta_{1}$ expression in a variety of malignancies was associated with increased tumorigenesis (31-34). The TGF- $\beta_{1}$ pathway has been implicated in many of these metastatic processes and it has been shown to dramatically impact the ability of tumor cells to spread throughout the body (35). Previous experiments have reported that TGF- $\beta_{1}$ can augment the aggressiveness of carcinomas that are resistant to its growth inhibiting effects (36), and promote breast carcinoma metastasis to the bone $(36,37)$. Padua et al (38) discovered that even transient exposure of breast cancer cells to the signaling molecule TGF- $\beta_{1}$ promoted their extravasation from blood vessels and entry into the lung. These effects are closely associated with MMP activities as mentioned above. TGF- $\beta_{1}$ binds to the type II TGF- $\beta$ receptor (T $\beta$ RII), which, in turn, recruits a TGF- $\beta$ type I receptor (T $\beta R I)$, into a heterotetrameric receptor complex, after that T $\beta R I$ is phosphorylated and activated. Activated T $\beta$ RI phosphorylates the receptor-specific Smad2/3, which enables them to oligomerize with the common mediator Smad4, to translocate to the nucleus and regulate target gene transcription through cooperation with other DNA-binding factors and/or transcription factors (39).

Although normal melanocytes are extremely sensitive to the antiproliferative effects of TGF- $\beta$, melanoma cells exhibit increased resistance, proportional to the stage of tumor progression. Melanoma cell proliferation is only moderately inhibited by TGF- $\beta$ in contrast to the strong antiproliferative effect exerted on normal melanocytes. Also, it has been shown that metastatic melanoma cell populations exhibit a further decreased response to TGF- $\beta$-dependent growth inhibition than melanoma cells originating from primary tumors (40). Yet, TGF- $\beta$ is perfectly capable of inducing Smad signaling and Smad-dependent transcription in melanoma cells (41). Contrary to other tumor types, no genetic alteration of TGF- $\beta$ signaling molecules has been identified in melanoma that could explain their resistance to the growth inhibitory activity of TGF- $\beta$. For example, it has been clearly established that a number of TGF- $\beta$ target genes are upregulated in melanoma cells exposed to TGF- $\beta$, in particular those involved in invasion and metastasis $(42,43)$. We previously discussed the possible mechanism associated with TGF- $\beta_{1}$, the expression of which may be decreased after hyperthermia in breast carcinoma MCF-7 cells. In the present study, we further revealed that the same regulation of TGF- $\beta_{1}$ occurred in mouse malignant melanoma B16F10 cells both in vivo and in vitro.

Our results revealed that hyperthermia at $43,45,47^{\circ} \mathrm{C}$ for 30 min downregulated the TGF- $\beta_{1}$ mRNA transcription level and protein expression in B16F10 cells. Smad4 protein was upregulated for a short time after hyperthermia treatment, while Smad4 mRNA showed an insignificant difference between the hyperthermic-treated and control group. We infer that the Smad4 mRNA transcription level should not be a key factor in its increased protein expression. The results here imply that expression of TGF- $\beta_{1}$ in malignant melanoma might be used to judge the curative effect and prognosis for hyperthermia.

In the in vivo test, we observed the mice of all groups after treatment, and tried to find out the reason for their death through anatomy. Although the survival period of the tumorburdened mice was significantly prolonged in the MFH-treated groups $(\mathrm{P}<0.05)$, no metastatic areas were found in the treatment and control groups, which could not be used to prove the suppressive effect of hyperthermia on metastasis in vivo yet it definitely resulted in a lower growth rate and less invasive ability in the treatment group.

Although, intracavity microwave coagulation therapy and radiofrequency ablation are the main methods of hyperthermia used in the clinic at present, both methods fail to achieve the set point of temperature intratumorally and achieve homogenous distribution of temperature $(44,45)$. Magnetic fluid hyperthermia is a promising approach to cancer therapy since it not only kills cancer cells directly, but can also alter the character of tumor cells with high metastatic potential, despite that the concrete mechanism needs to be further researched.

From the present study, we confirmed that hyperthermia induced by magnetic fluid can be used safely to inhibit tumor growth in a mouse model without heat damage to surrounding normal tissue. A well-homogenized distribution of high intratu- 
moral temperature can be achieved by image guidance which we did not make use of in the present study. As dosage of radiotherapy is limited by the tolerance of surrounding normal tissue, the temperature of hyperthermia should also be limited. For safe consideration, heating radiator can hardly be cut off between tumor and normal tissues even by image guidance, so local hyperthermia induced by magnetic fluid may be far from a radical treatment in the clinic. However, this method can be used as an effective cytoreductive treatment thus providing a greater chance of efficacy of further treatment such as surgery.

In conclusion, our study suggests that hyperthermia heating at $43^{\circ} \mathrm{C}$ or above can strongly reduce the proliferation and invasive ability of B16F10 cells in vitro, and their protease production can be decreased as well. In addition, magnetic fluid hyperthermia at 45 and $50^{\circ} \mathrm{C}$ significantly inhibited the growth of malignant melanoma in a mouse model and suppressed the expression of TGF- $\beta_{1}$ in tumor tissue. Therefore, our study implies that the expression of TGF- $\beta_{1}$, MMP-2 and MMP-9 in malignant melanoma may be used to judge the curative effect and prognosis for hyperthermia. Moreover, we can prospect that, magnetic fluid hyperthermia may be an effective adjuvant therapy, not destroying malignant melanoma cells directly, but suppressing the ability of invasiveness and mobility of the remnant carcinoma cells.

\section{Acknowledgements}

This research was supported by the National Natural Science Foundation of China (nos. 30571779 and 10775085) and the Yu-Yuan Medical Foundation of Tsinghua University.

\section{References}

1. Kim CJ, Reintgen DS and Balch CM: The new melanoma staging system. Cancer Control 9: 9-15, 2002.

2. Hofmann UB, Westphal JR, Van Muijen GNP and Ruiter DJ: Matrix metalloproteinases in human melanoma. J Invest Dermatol 115: 337-344, 2000.

3. Vihinen P and Kahari VM: Matrix metalloproteinases in cancer: prognostic markers and therapeutic targets. Int J Cancer 99: 157-166, 2002

4. Krasagakis K, Tholke D, Farthmann B, Eberle J, Mansmann U and Orfanos CE: Elevated plasma levels of transforming growth factor (TGF)-beta1 and TGF-beta2 in patients with disseminated malignant melanoma. Br J Cancer 77: 1492-1494, 1998.

5. Krasagakis K, Garbe C, Schrier PI and Orfanos CE: Paracrine and autocrine regulation of human melanocyte and melanoma cell growth by transforming growth factor beta in vitro Anticancer Res 14: 2565-2571, 1994.

6. Rodeck U, Melber K, Kath R, Menssen HD, Varello M, Atkinson B and Herlyn M: Constitutive expression of multiple growth factor genes by melanoma cells but not normal melanocytes. J Invest Dermatol 97: 20-26, 1991.

7. Rodeck U, Bossler A, Graeven U, Fox FE, Nowell PC, Knabbe C and Kari C: Transforming growth factor beta production and responsiveness in normal human melanocytes and melanoma cells. Cancer Res 54: 575-581, 1994.

8. Van Belle P, Rodeck U, Nuamah I, Halpern AC and Elder DE: Melanoma-associated expression of transforming growth factorbeta isoforms. Am J Pathol 148: 1887-1894, 1996.

9. Nagashima K, Takagi R and Hoshina H: Effect of local hyperthermia on metastases in oral squamous cell carcinoma. Int J Oral Maxillofac Surg 31: 84-89, 2002.

10. Sato T, Sawaji Y, Matsui N, Sato H, Motoharu S, Mori Y and Ito A: Heat shock suppresses membrane type 1-matrix metalloproteinase production and progelatinase A activation in human fibrosarcoma HT-1080 cells and thereby inhibits cellular invasion. Biochem Biophys Res Commun 265: 189-193, 1999.

11. Nathanson SD, Cerra SD, Hetzel FW, et al: Changes associated with metastasis in B16-F1 melanoma cells surviving heat. Archives Sur 125: 216-219, 1990.
12. Jordan A, Scholz R, Wust P, Fakhling H and Felix R: Magnetic fluid hyperthermia (MFH): cancer treatment with AC magnetic field induced excitation of biocompatible superparamagnetic nanoparticles. J Magn Magn Mater 201: 413-419, 1999.

13. Du LH, Zhou JM, Wang XW, Sheng L, Wang GH, Xie XX, Zhao LY, Liao YP and Tang JT: Effect of local hyperthermia induced by nanometer magnetic fluid on the rabbit VX2 liver tumor model. Prog Nat Sci 19: 1705-1712, 2009.

14. Wilhelm C, Fortin JP and Gazeau F: Tumour cell toxicity of intracellular hyperthermia mediated by magnetic nanoparticles. J Nanosci Nanotechnol 7: 2933-2937, 2007.

15. Gao FP, Cai YY, Zhou J, Xie XX, Ouyang WW, Zhang YH, Wang XF, Wang XW, Zhao LY and Tang JT: Pullulan acetate coated magnetite nanoparticles for hyperthermia: preparation, characterization and in vitro experiments. Nano Res 3: 23-31, 2010.

16. Landeghem FK, Maier-Hauff K, Jordan A, Hoffmann KT, Gneveckow U, Scholz R, Thiesen B, Buck W and Deimling AV: Post-mortem studies in glioblastoma patients treated with thermotherapy using magnetic nanoparticles. Biomaterials 30: 52-57, 2009.

17. Suzuki M, Shinkai M, Honda H and Kobayashi T: Anticancer effect and immune induction by hyperthermia of malignant melanoma using magnetite cationic liposomes. Melanoma Res 13:129-135, 2003.

18. Hilger I, Hergt R and Kaiser WA: Use of magnetic nanoparticle heating in the treatment of breast cancer. IEE Proc Nanobiotechnol 152: 33-39, 2005.

19. Johannsen M, Gneveckow U, Eckelt L, Feussner A, Waldofner N, Scholz R, Deger S, Wust P, Loening SA and Jordon A: Clinical hyperthermia of prostate cancer using magnetic nanoparticles: presentation of a new interstitial technique. Int J Hyperthermia 21: 637-647, 2005.

20. Jordan A and Maier-Hauff K: Magnetic nanoparticles for intracranial thermotherapy. J Nanosci Nanotechnol 7: 4604-4606, 2007.

21. Johannsen M, Thiesen B, Jordan A, Taymoorian K, Gneveckow U, Waldofner N, Scholz R, Koch M, Lein M, Jung K and Loening SA: Magnetic fluid hyperthermia (MFH) reduces prostate cancer growth in the orthotopic Dunning R3327 rat model. Prostate 64: 283-392, 2005

22. Ito A, Tannka K, Kondo K, Shinkai M, Honda H, Matsumoto K, Saida T and Kobayashi T: Tumor regression by combined immunotherapy and hyperthermia using magnetic nanoparticles in an experimental subcutaneous murine melanoma. Cancer Sci 94: 308-313, 2003.

23. Jordan A, Scholz R, Maier-Hauff K, van Landeghem FK, Waldoefner N, Teichgraeber U, Pinkemelle J, Brugn H, Neuman F, Thiesen B, et al: The effect of thermotherapy using magnetic nanoparticles on rat malignant glioma. J Neurooncol 78: 7-14, 2006.

24. Xie XX, Shao XF, Gao FP, Jin HK, Zhou JM, Du LH, Zhang YY, Ouyang WW, Wang XW, Zhao LY, et al: Effect of hyperthermia on invasion ability and TGF- $\beta 1$ expression of breast carcinoma MCF-7 cells. Oncol Rep 25: 1573-1579, 2011.

25. Houghton AN and Polsky D: Focus on melanoma. Cancer Cell 2: 275-278, 2002.

26. Chiang WC, Wong YK, Lin SC, Chang KW and Liu CJ: Increase of MMP-13 expression in multi-stage oral carcinogenesis and epigallocatechin-3-gallate suppress MMP-13 expression. Oral Dis 12: 27-33, 2006.

27. Puente XS, Sanchez LM, Overall CM and Lopez-Otin C: Human and mouse proteases: a comparative genomic approach. Nat Rev Genet 4: 544-558, 2003.

28. Nelson AR, Fingleton B, Rothenberg ML and Matrisian LM: Matrix metalloproteinases: biologic activity and clinical implications. J Clin Oncol 18:1135-1149, 2000.

29. Ispanovic E and Haas TL: JNK and PI3K differentially regulate MMP-2 and MT1-MMP mRNA and protein in response to actin cytoskeleton reorganization in endothelial cells. Am J Physiol Cell Physiol 291: 579-588, 2006.

30. Sawaji Y, Sato T, Seiki M and Ito A: Heat shock-mediated transient increase in intracellular 3',5'-cyclic AMP results in tumor specific suppression of membrane type 1-matrix metalloproteinase production and progelatinase A activation. Clin Exp Metastasis 18: $131-138,2000$.

31. Welm AL: TGFbeta primes breast tumor cells for metastasis. Cell 133: 27-28, 2008

32. Hasegawa Y, Takanashi S, Kanehira Y, Tsushima T, Imai T and Okumura K: Transforming growth factor-beta1 level correlates with angiogenesis, tumor progression, and prognosis in patients with nonsmall cell lung carcinoma. Cancer 91: 964-971, 2001. 
33. Saito H, Tsujitani S, Oka S, Kondo A, Ikeguchi M, Maeta M and Kaibara N: The expression of transforming growth factorbeta1 is significantly correlated with the expression of vascular endothelial growth factor and poor prognosis of patients with advanced gastric carcinoma. Cancer 86: 1455-1462, 1999.

34. Tsushima H, Kawata S, Tamura S, Ito N, Shirai Y, Kiso S, Imai Y, Shimomukai H, Nomura Y, Matsuda Y and Matsuzawa Y: High levels of transforming growth factor beta 1 in patients with colorectal cancer: association with disease progression. Gastroenterology 110: 375-382, 1996.

35. Oft M, Heider KH and Beug H: TGF-beta signaling is necessary for carcinoma invasiveness and metastasis. Curr Biol 8: 1243-1252, 1998.

36. Yin JJ, Selander K, Chirgwin JM, Dallas M, Grubbs BG, Wieser R, Massague J, Mundy GR and Guise TA: TGF-beta signaling blockade inhibits PTHrP secretion by breast cancer cells and bone metastases development. J Clin Invest 103: 197-206, 1999.

37. Cui W, Fowlis DJ, Bryson S, Duffie E, Ireland H, Balmain A and Akhurst RJ: TGF beta1 inhibits the formation of benign skin tumors, but enhances progression to invasive spindle carcinomas in transgenic mice. Cell 86: 531-542, 1996.

38. Padua D, Zhang XHF, Wang QQ, Nadal C, Gerald WL, Gomis RR and Massague J: TGFbeta primes breast tumors for lung metastasis seeding through angiopoietin-like 4. Cell 133: 66-77, 2008.

39. Krasagakis K, Kruger-Krasagakes S, Fimmel S, Eberle J, Tholke D, von der Ohe M, Mansmann U and Orfanos CE: Desensitization of melanoma cells to autocrine TGF-beta isoforms. J Cell Physiol 178: 179-187, 1999.
40. Janji B, Melchior C, Gouon V, Vallar L and Kieffer N: Autocrine TGF-beta-regulated expression of adhesion receptors and integrin-linked kinase in HT-144 melanoma cells correlates with their metastatic phenotype. Int J Cancer 83: 255-262, 1999.

41. Miyoshi E, Nishikawa A, Ihara Y, Saito H, Uozumi N, Hayashi N, Fusamoto H, Kamada $\mathrm{T}$ and Taniguchi N: Transforming growth factor beta up-regulates expression of the $\mathrm{N}$-acetyl glucoseminyl transferase V gene in mouse melanoma cells. J Biol Chem 270: 6216-6220, 1995

42. Park SS, Li L, Korn TS, Mitra MM and Niederkorn JY: Effect of transforming growth factor-beta on plasminogen activator production of cultured human uveal melanoma cells. Curr Eye Res 15: 755-763, 1996.

43. Rodeck U, Nishiyama T and Mauviel A: Independent regulation of growth and SMAD-mediated transcription by transforming growth factor beta in human melanoma cells. Cancer Res 59: 547-550, 1999.

44. Hilger I, Hiergeist R, Hergt R, Winnefeld K, Schubert H and Kaiser W: Thermal ablation of tumors using magnetic nanoparticles: an in vivo feasibility study. Invest Radiol 37: 580-586, 2002.

45. Brusentsova NA, Nikitinb L, Brusentsovac T, Brusentsava TN, Kuznetsov AA, Beyburtskiy FS, Shumakov LI and Jurchenko NY: Magnetic fluid hyperthermia of the mouse experimental tumor. J Magn Magn Mater 252: 378-380, 2002. 